\title{
Sea Weed Based Liquid Fertilizer as a Source of Plant Nutrition - A Review
}

\author{
K. Shruthi Nagaral*, B. Kisan and A.S. Haleypyati \\ Department of Molecular Biology and Agricultural Biotechnology University of Agricultural \\ Sciences, Raichur, Karnataka, India \\ *Corresponding author
}

\section{A B S T R A C T}

Plant nutrients are classified as major (Nitrogen $(\mathrm{N})$, Phosphorus $(\mathrm{P})$ and Potassium $(\mathrm{K})$, calcium $(\mathrm{Ca})$, magnesium $(\mathrm{Mg})$ and sulfur $(\mathrm{S})$. They are also

Keywords

Sea weed,

Liquid fertilizer,

Plant nutrition

Article Info

Accepted:

16 March 2018

Available Online:

10 April 2018 enquired in relatively large amounts but are less likely to be deficient. Micronutrients [boron(B), copper $(\mathrm{Cu})$, iron $(\mathrm{Fe})$, manganese $(\mathrm{Mn})$, molybdenum (Mo) and zinc $(\mathrm{Zn}) 0$. Considering ill effects of chemical fertilizers and slow release of nutrients by soil applied organic fertilizers; foliar application of organically chelated micronutrient fertilizers can be an ideal option to nourish the crops by avoiding short term mineral deficiencies. Fertilizers derived from seaweeds are found to be superior to chemical fertilizers due to high level of organic matter, micro and macro elements, vitamins and fatty acids. Seaweed extracts are allowed as fertilizer for organic farming production practices whereas synthetic chemical fertilizers are prohibited for organic food production. Fertilizers derived from seaweeds are found to be superior to chemical fertilizers due to high level of organic matter, micro and macro elements, vitamins and fatty acids. Hence the review dwells on utility of sea weed as plant nutrition.

\section{Introduction}

The nutrition contains mineral nutrients, vitamins, and micronutrients, which enhance the plant growth. It can be applied as foliar spray or directly applied to the soil as an organic nutrition source. Fertilizers derived from seaweeds are found to be superior to chemical fertilizers due to high level of organic matter, micro and macro elements, vitamins and fatty acids. Seaweed extracts are allowed as fertilizer for organic farming production practices whereas synthetic chemical fertilizers are prohibited for organic food production. Now-a-days seaweed fertilizers are gaining popularity for achieving higher crop production and soil quality improvement. Seaweed extracts can be manufactured in liquid and powder form and used as fertilizers for all type of crops, grasses 
and trees. Seaweed extracts on their own are unlikely to remedy a severe mineral deficiency and the appropriate element should be applied, preferably in combination with seaweed extract, to further stimulate growth. Hence, considering ill effects of chemical fertilizers and slow release of nutrients by soil applied organic fertilizers; foliar application of organically chelated micronutrient fertilizers can be an ideal option to nourish the crops by avoiding short term mineral deficiencies. In this context, an organically chelated multi-micronutrient liquid fertilizer can supply most of micronutrients at the proper growth stages like flowering, fruit setting stage.

Macronutrient formulation with seaweed extracts and growth regulators required to be formulated for optimum growth

\section{Macronutrients}

Nitrogen $(\mathrm{N})$, phosphorus $(\mathrm{P})$, potassium $(\mathrm{K})$, calcium $(\mathrm{Ca})$, sulfur $(\mathrm{S})$, magnesium $(\mathrm{Mg})$, sodium $(\mathrm{Na})$.

The macronutrients are consumed in larger quantities; hydrogen, oxygen, nitrogen and carbon contribute to over $95 \%$ of a plants' entire biomass on a dry matter weight basis. Micronutrients are present in plant tissue in quantities measured in parts per million, ranging from 0.1 to $200 \mathrm{ppm}$, or less than $0.02 \%$ dry weight.

\section{Nitrogen (N)}

It is required for making protein (one or more $\mathrm{N}$ per amino acid), Base pairs for RNA/DNA, Prosthetic groups for protein (ex.: heme group of chlorophyll), Hormones (ABA, cytokinins), Metal uptake (phytosiderophores) and transport in xylem \& phloem (ex: $\mathrm{Cu}$ with amines), Osmoregulation (ex.: lettuce and spinach, which may accumulate 0.1 M NO3- in vacuoles), Chemical defences, alkaloids, misc. biochemicals (ex: mescaline, cocaine, morphine, nicotine, caffeine, quinine). Mild N deficiency will restrict plant growth, but often in a subtle manner that can only be assessed by comparison to plants grown with an adequate $\mathrm{N}$ supply. Moderate $\mathrm{N}$ deficiency will cause leaves to be light green or yellowish. Severe symptoms include necrosis (tissue death) starting at the tips of older leaves, with the tissue death developing a Vpattern down the midrib toward the base of the leaf.

\section{Phosphorus (P)}

In living organisms is most notable in the ubiquitious ATP/ADP energy transport and storage compounds. Additionally, sugar phosphates form the "rails" of the nucleic acids DNA and RNA (which N-containing bases forming the "rungs"). Phospholipids are an important constituent of membrane chemistry and phosphor proteins are essential for life functions.

\section{Potassium (K)}

Potassium is the "universal cation" in biological systems. Only one oxidation state, soluble with all biologically significant anions (except one!) and at all $\mathrm{pH}$ values. Nontoxic, even at soil and plant levels far in excess of minimum requirements for optimum growth. Phloem-mobile.

\section{Calcium (Ca)}

Calcium is present in the cytoplasm at levels that would indicate that it is a micronutrient, $\sim 0.1 \mu \mathrm{M}$, in order to prevent interference with the high levels of P. Nonetheless, small fluctuations in $\mathrm{Ca}$ levels in the cytoplasm are part of signalling mechanisms for environmental stress. Ca pumps are directed out of the cytoplasm, either to vacuoles, 
where it may be precipitated as calcium oxalate, or across the plasmalemma. The function of the majority of plant $\mathrm{Ca}$ is structural, in the cell walls of shoots and roots.

\section{Sulphur (S)}

Most familiar function of $\mathrm{Mg}$, as the central ion in chlorophyll molecule, accounts for $<25 \%$ of total plant $\mathrm{Mg}$. $\mathrm{Mg}$ in the cytoplasm is related to enzyme activation: for example, the substrate for ATPases is MgATP. Additional $\mathrm{Mg}$ is present in the cell wall. No toxicity to sulfate beyond salinity, $\mathrm{S}$ uptake beyond needs stored in part as sulfate. Deficiency symptoms are yellowing of whole plant, moderately phloem mobile. Response to $\mathrm{S}$ fertilizer in many crops and regions. With the reduction of sulphur at the smokestacks, agriculture may be losing the only benefit of acid rain!

\section{Magnesium (Mg)}

The most familiar function of $\mathrm{Mg}$, as the central ion in chlorophyll molecule, accounts for $<25 \%$ of total plant $\mathrm{Mg}$. $\mathrm{Mg}$ in the cytoplasm is related to enzyme activation: for example, the substrate for ATPases is MgATP. Additional Mg is present in the cell wall.

Magnesium deficiencies in soils are relatively rare as far as plants are concerned, but animals fed on Mg-deficient forage may develop hypomagesameia (grass tetany). "Excess" Mg is known almost only in soils derived from serpentine or olivene, both $\mathrm{Mg}$ rich rocks, in which the exchangeable $\mathrm{Ca} / \mathrm{Mg}$ ratio is $\sim 1 / 5$ instead of the more common $4 / 1$ to $1 / 1$; such soils often also contain toxic, high levels of bioavailable metals, among them $\mathrm{Ni}$, which together with high $\mathrm{Mg}$ limit the distribution of "normal" vegetation, leading to "serpentine barrens".

\section{Sodium (Na)}

Amino acids: cysteine, methionine. OrganicN/organic-S in plants typically has a 30-40:1 molar ratio.

Coenzymes and prosthetic groups, glutathionine: antioxidant and precursor to phytochelatins, alliins in allium (w/ allinase produce pungency in onions) and glycosinolates in brassica (produces isothiocynates) for chemical defenses and $\mathrm{S}$ storage.

\section{Sea weed extract as plant nutrition}

Seaweed contains provides following nutrition to plants:

The first records of seaweed being processed come from China in $2700 \mathrm{BC}$ and have been using it for human and animal consumption ever since, Initially in the UK, agricultural use of seaweed was restricted to bulk fresh weed which was used as a manure and soil conditioner. As transport and labour costs rose and chemical fertilizers became more readily available so raw seaweed was replaced.

\section{Auxins}

These plant hormones have been identified in seaweed and more recently in extracts

\section{Gibberellins}

Gibberellin activity has been identified in seaweed extracts.

\section{Cytokinins}

Cytokinins are plant growth hormones closely involved in cell division, protein, carbohydrate and chlorophyll synthesis are also present in sea weed extract. 


\section{Betaines}

Betaines are modified amino acids which have been isolated from seaweeds and which have several functions similar to those of cytokinins.

\section{Sugars}

More recently polysaccharides isolated from seaweed have been shown to stimulate the plant's natural defence mechanism (Fournier Algal polysaccharides can act as elicitors for plant defence). Finnie and Van Staden (1985). Demonstrated that tomato root response to seaweed extract was due to organic compounds and one is drawn to conclude that the major crop responses result from the action of the betaines and cytokinins although there may be further interactions with other constituents.

The field experiment conducted during the rainy (kharif) season in Indian in 2006 to study the effects of foliar applications of different concentrations of seaweed extract (prepared from Kappaphycus alvarezii) on nutrient uptake, growth and yield of soybean [Glycine max (L.) Merr.] Grown under rainfed conditions without the application of chemical fertilizers.

The foliar spray was applied twice at seven concentrations $(0 ; 2,4,8,12$ and $16 \% \mathrm{v} / \mathrm{v})$ of seaweed extract. Foliar applications of seaweed extract significantly enhanced yield parameters. The highest grain yield was recorded with applications of $15 \%$ seaweed extract, followed by $12.5 \%$ seaweed extract that resulted in $57 \%$ and $46 \%$ increases respectively compared to the control. The maximum straw yield was also achieved with 15\% seaweed extract application. Improved nutrient uptake (N, P, K and S) was also observed with seaweed extract applications. Thus, under rainfed soybean production, foliar applications of sea weed extract could be a promising option for yield enhancement.

In the study conducted by Anna Kocira et al., (2013), the application of Ecklonia maxima extract (Kelpak SL - a water soluble concentrate) was optimized and its impact on yield, nutraceutical and nutritional potential of Phaseolus vulgaris L. (var. Aura and Toska) was measured. During the growing season, $0.2 \%$ and $0.4 \%$ solution of Kelpak SL was applied by single and double spraying of plants. These four treatments with Kelpak SL were compared with the control, where no bio stimulator was applied. Kelpak SL treatments stimulated the yield of both cultivars studied. The application of its maxima extract had no effect on the content of starch, free sugars or proteins in seeds of either of the tested cultivars there is a growing interest in using cultivation methods such as natural biostimulants, which improve yield without any negative effects on plant quality. Such a strategy allows for increasing biomass production, but also induces the natural resistance of plants, as well as improves nutraceutical quality of plant food (Vallad and Goodman, 2004; Zodape et al., 2010; Kavipriya et al., 2001; Złotek and $\mathrm{Wo}^{\prime}$ jcik, 2014).

The use of the seaweed extract increased significantly $\mathrm{N}, \mathrm{P}$ and $\mathrm{K}$ uptake by grains at higher concentrations ( $7.5 \%$ and above) and reached maximum at $12.5 \%, 15 \%$ and $15 \%$ application rate respectively compared with control (Rathore, 2009). Sulphur uptake by grains was significantly increased at $10 \%$. And above levels of seaweed extract applications. Highest P uptake by straw was observed (Crouch et al., 1990; Turan and Köse, 2004; Nelson and Van Staden, 1984; Mancuso et al., 2006). Noted increased uptake of $\mathrm{Mg}, \mathrm{K}$ and $\mathrm{Ca}$ in lettuce with seaweed concentrate application (Turan and Kose, 2004). And Mancuso et al., (2006) also 
observed increased uptake of $\mathrm{N}, \mathrm{P}, \mathrm{K}$ and $\mathrm{Mg}$ in grapevines and cucumber with application of seaweed extract. The presence of marine bioactive substances in seaweed extract improves stomata uptake efficiency in treated plants compared to non-treated plants. Bio stimulants, even those containing minerals, are not able to supply all the essential nutrients in the quantities required by plants but may enhance root growth of plant subjected to stress possibly by increasing the antioxidant defence system (Zhang and Schmidt, 1999; Zhang and Schmidt, 2000; Zhang et al., 2003). In addition to proper mineral fertilization, bio stimulants can enhance the effectiveness of fertilizers as well as nutrient utilization from soil (Frankenberger and Arshad, 1995). To evaluate the use of foliar fertilization to increase the productivity of Egyptian agriculture in the case of $\mathrm{Zn}-, \mathrm{Mn}^{-}$and $\mathrm{Fe}$ deficiency, field trials in different regions (Nile Delta, Middle and North-West Egypt) with relevant crops at those locations (Alexandarina clover, Faba bean, Soya bean, Bush bean, Wheat, Maize, Cotton, Potato, Rice, Grape, Orange) were conducted from 1981/81 till 1984. The used foliar fertilizers (Zn-Chelate, Zn-Mn-Fe-Chelate-Mix, Wuxal suspensions, Wuxal liquid, Fetrilon combi, Metalosate) caused yield increases between 1 and $51 \%$ compared to the untreated check. With the exception of Faba bean and Orange, where Zn-Chelate resp. Chelate-Mix gave the best results, the compound foliar fertilizers with the formula N-Zn-Mn-Fe and N-P-K$\mathrm{Mn}-\mathrm{Fe}$ (Wuxal suspensions and Wuxal liquid) produced the highest yields.

\section{References}

Anna Kocira A, Michał S, Wieca B, Sławomir Kocira C, Urszula Złotek bAnna Jakubczyk Enhancement of yield, nutritional and nutraceutical properties of two common bean cultivars following the application of seaweed extract(Ecklonia maxima) Asian Pacific Journal of Reproduction 2013; 2(2): 119-125.

Crouch, I.J., Beckett, R.P., Van Staden, J., 1990. Effect of seaweed concentrate on the growth and mineral nutrition of nutrient stress lettuce. Journal of Applied Phycology 2, 269-272.

Finnie J and Van Staden. Effect of seaweed concentrate and applied hormones on in vitro culture tomato roots. $J$ Plant Phys. 120 1985, 215.

Fournier Algal polysaccharides can act as elicitors for plant defence. New Phytologist.

Frankenberger, W.T., and Arshad, M., 1995. Phytohormones in Soils. Marcel. Dekker, New York, USA.

Kavipriya, R., Dhanalakshmi, P.K., Jayashree, S., Thangaraju, N., 2001. Seaweed extract as a biostimulant for legume crop, green gram. J. Ecobiotechnol. 3, 16-19.

Mancuso, S., Azzarello, E., Mugnai, S., Briand, X., 2006. Marine bioactive substances (IPA extract) improve foliar ion uptake and water tolerance in potted Vitis vinifera plants. Advances in Horticultural Science 20, 156-161.

Mancuso, S., Azzarello, E., Mugnai, S., Briand, X., 2006. Marine bioactive substances (IPA extract) improve foliar ion uptake and water tolerance in potted Vitis vinifera plants. Advances in Horticultural Science 20, 156-161.

Nelson, W.R., and Van Staden, J., 1984. The effect of seaweed concentrate on the growth of nutrient-stressed, greenhouse cucumbers. Horticultural Science 19, 81-82.

Nelson, W.R., and Van Staden, J., 1984. The effect of seaweed concentrate on the growth of nutrient-stressed, greenhouse cucumbers. Horticultural Science 19, 81-82. 
Rathore, S.S. South African Journal of Botany 75 (2009) 351-355.

Turan, M., and Kose, C., 2004. Seaweed extracts improve copper uptake of grapevine. Acta Agriculturae Scandinavica. Section B, Soil and Plant Science 54, 213-220.

Turan, M., and Köse, C., 2004. Seaweed extracts improve copper uptake of grapevine. Acta Agriculturae Scandinavica. Section B, Soil and Plant Science 54, 213-220.

Vallad, G.E., and Goodman, R.M., 2004. Systemic acquired resistance and induced systemic resistance in conventional agriculture. Crop Sci.44, 1920-1934.

Zhang, X., and Schmidt, R.E., 1999. Antioxidant response to hormone containing product in Kentucky bluegrass subjected to drought. Crop Science 39, 545-551.
Zhang, X., and Schmidt, R.E., 2000. Hormone-containing products' impact on antioxidant status of tall fescue and creeping bentgrass subjected to drought. Crop Science 40, 1344-1349.

Zhang, X., Ervin, E.H., Schmidt, E.R., 2003. Plant growth regulators can enhance the recovery of Kentucky bluegrass sod from heat injury. Crop Science 43, 952956.

Złotek, U., and Wo' jcik, W., 2014. Effect of arachidonic acid elicitation on lettuce resistance towards Botrytis cinerea. Sci. Hortic. 179, 16-20.

Zodape, S.T., Mukhopadhyay, S., Eswaran, K., Reddy, M.P., Chikara, J., 2010. Enhanced yield and nutritional quality in green gram (Phaseolus radiata L.) treated with seaweed (Kappaphycus alvarezii) extract. J. Sci. Ind. Res. 69, $468-471$.

\section{How to cite this article:}

Shruthi Nagaral, K., B. Kisan and Haleypyati, A.S. 2018. Sea Weed Based Liquid Fertilizer as a Source of Plant Nutrition - A Review. Int.J.Curr.Microbiol.App.Sci. 7(04): 1984-1989. doi: https://doi.org/10.20546/ijcmas.2018.704.228 